\title{
Impact of Microfinance on Poverty Alleviation: A Study in the Southern Part of Bangladesh
}

\author{
Badiuzzaman $^{1}$, Md. Hasan Uddin ${ }^{2}$, Afjal Hossain ${ }^{3 *}$ \\ ${ }^{1}$ Professor, Department of Economics and Sociology, Patuakhali Science and Technology University, Patuakhali, BANGLADESH \\ ${ }^{2}$ Associate Professor, Department of Finance and Banking, Patuakhali Science and Technology University, Patuakhali, BANGLADESH \\ ${ }^{3}$ Associate Professor, Department of Marketing, Patuakhali Science and Technology University, Patuakhali, BANGLADESH \\ "E-mail for correspondence: hossainafjal@gmail.com
}

https://doi.org/10.18034/abr.v10i2.465

\begin{abstract}
Poverty is the incapability of a person to meet his basic need like food, cloth, and shelter. Every country has to face poverty across the world. Bangladesh has also been suffering from poverty. Micro Finance Institutions in Bangladesh are trying to reduce the poverty alleviation over the country. The purpose of this study is to identify the impact of different microfinance services to poverty reduction in Bangladesh. A structured questionnaire was used to collect the data from respondents in Barishal division, Bangladesh, and OLS regression was estimated to find out the impact of microfinance services to the poverty reduction in Bangladesh. Results show that micro-credit mostly influences poverty reduction. Savings, micro-insurance, and training also influence the poverty reduction in Bangladesh. The implication of the study is that microfinance service provisions should be more user-friendly for the customers so that the services can be advanced to the locals of the different regions of Bangladesh for facilitating the rapid economic growth. Financial education may be introduced for a better understanding of microfinance services collection, usage, and for return policy. Policymakers may also provide some guidelines to fight poverty for their rest of life.
\end{abstract}

Key words: Micro-credit, micro-insurance, savings, training, poverty alleviation and Bangladesh

\section{INTRODUCTION}

Microfinance is a form of financial development that has primarily focused on alleviating poverty through providing financial services to the poor. Most people thought that microfinance means micro-credit i.e. lending small amounts of money to the poor. According to Morduch (1999), microfinance refers to provision of financial services namely, loans, savings, insurance, or transfer services to low-income households. Otieno et al. (2013) further describes microfinance as small loans, savings mobilization and training offered to the poor to enable them to create selfemployment by starting their own businesses and thus generating income. Anyanwu (2004) stated that microfinance refers to an array of financial services like loans, savings and insurance. The services basically provide to the people who have no collateral or qualify for a standard bank loan. They may be the poor entrepreneurs or the small business owners. Ledgerwood (1999) also stated that the financial services not only include savings and credit but also other financial services like insurance and payment services. Therefore, microfinance involves the provision of financial services providing to the poor who are unable to obtain such services from the formal financial sector, living both in urban and rural areas. The services may include credit, saving and insurance (Khan and Rahaman, 2007; Wanchoo, 2007; Bakhtiari, 2006). According to Barr (2004), the services may include insurance, transactional services and savings too. Microfinance directly contributes to the economic growth through the value creation of small entrepreneurship and businesses, positive spill over's, improvements in human development indicators (health, nutrition, and education), reduction in inequality and poverty (Ravallion, 2001). Kai and Hamori (2009) analyzed microfinance towards inequality of 61 developing countries people. They found that microfinance tends to reduce income inequity directly by easing credit constraints to the poor.

A number of Literatures on microfinance studies from various disciplines are studied to have an idea about the present piece of work. Most of the studies suggest that microfinance not only reduce the poverty of the households 
but also works for the well-being of the households at deferent levels such as asset acquisition, household nutrition, health, food security, children education, women's empowerment, and social cohesion (Armendáriz de Aghion and Morduch, 2000; Armendáriz and Morduch, 2005, 2010; Schuler et al., 1996; Littlefield et al. 2003; Roodman and Morduch, 2014). However, recently the impact of microfinance has been questioned and many studies argue that the impact of microfinance is divergent between positive, no impact and even negative impact (Angelucci et al., 2013; Ganle et al., 2015; Van Rooyen et al., 2012). The literature acclaims that the impact of microfinance works differently from one context to another and the impact is dependent on the population density, attitudes to debt, group-cohesion, enterprise development, financial literacy, financial service providers and other (Armendáriz and Morduch, 2005). Bangladesh has also been able to draw the attention of the world community heralding new approaches to poverty alleviation through operations of microfinance among poor households. According to Schwab (2017), Bangladesh ranked $77^{\text {th }}$ on availability and $86^{\text {th }}$ on affordability of financial service out of 137 countries. At present, microfinance is an integral part of Bangladesh's economy and the growth of financial sector depends on a larger extent of the socio-economic, macro-economic and financial stability of a country. Presently, it plays a much more important role in Bangladesh than in the 1990s. In the time of 1990s, the main purpose of microfinance was limited to savings mobilization and credit disbursement.

Microfinance has created much fervor among researchers, development economists in particular to research on emergence, roles, objectives and methods of microfinance program as well as its impact of microfinance on poverty alleviation. The Peoples' Republic of Bangladesh established the Microcredit Regulatory Authority (MRA) in 2006 and started licensing in 2007 in order to give license, monitor and oversee the Bangladeshi MFIs. At the end of June 2017, the total number of licensed MFIs was 783 of which 84 licenses were cancelled (see the details of MFIs in Bangladesh in appendix 1). Like other sectors namely, Bangladesh Bank and Bangladesh Securities \& Exchange Commission, MRA is also working to maintain the integrity of microfinance sector.

The study is, thus, important in providing vital information which will help take effective measures by MFIs management and policy makers to improve the MFIs performance. This can also help microfinance institutions identifying innovative options and institutional arrangements that would serve as input to the policy makers in formulating economic empowering policy. The specific objectives of the study are-

- To determine the effect of micro-credit by microfinance institutions on poverty reduction;

- To establish the impact of savings by microfinance institutions on poverty reduction;

- To find out the effect of training by microfinance institutions on poverty reduction; and
- To determine the impact of micro-insurance by microfinance institutions on poverty reduction.

The next section of the study details about the materials and methods of the study followed by results and discussion. Conclusions are drawn in the last section of the study.

\section{MATERIALS AND METHODS}

This study is a descriptive study based research in which the respondents were selected based on some systematic procedures. According to Micro-credit Regulatory Authority (MRA, 2017), microfinance services can be broken into three broad categories namely, micro-credit, micro-savings and micro-insurance. Based on the literature discussed in the previous section, the following conceptual framework is developed for this study.

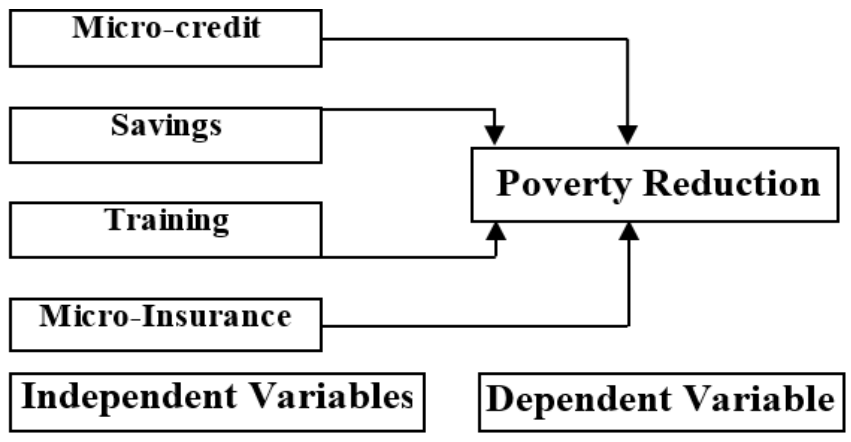

Figure 1: Proposed conceptual framework for this study

A questionnaire was prepared following the above conceptual framework and was used to collect the data from the respondents who have received MFI services for the last five years during the period of 2013 to 2018 at Barishal division in Bangladesh. In a total of 200 customers of the four different MFIs namely; Grameen Bank, BRAC, ASA and other MFIs were equally interviewed in the year of 2018. Researcher at first, pre-notified the potential respondents of the intended survey, then they were provided a selfadministered questionnaire. The data were then collected with the help of systematic convenience sampling technique and then these were picked shortly and made follow up calls to clarify queries as well as prompt the respondents to fill the questionnaires. The data were then organized into excel sheet to ready for estimation. The following multivariate regression model was developed to find out the effect of each of the variables following Gujarati (2009):

$\mathrm{Y}=\alpha_{0}+\delta_{1} \mathrm{X}_{1}+\delta_{2} \mathrm{X}_{2}+\delta_{3} \mathrm{X}_{3}+\delta_{4} \mathrm{X}_{4}+\varepsilon$

Where, $\mathrm{Y}$ is poverty reduction as the dependent variable, $\alpha_{0}$ is constant, $\delta_{\mathrm{i}}$ are the parameters to be estimated for the independent variables, $X_{i}$ are the independent variables, namely, micro-credit, micro-insurance, savings and training and $\varepsilon$ is the error term to capture unexplained variations in the model and which is assumed to be normally distributed with mean zero and constant variance. The researchers applied OLS regression model with the help of SPSS 21 version. 


\section{RESULTS AND DISCUSSION}

Microfinance provides different services especially microcredit, micro-insurance, savings and training to the different types of people for the development of their basic needs, lifestyle, and savings and so on. The following table illustrates the effect of micro-credit on poverty reduction.

Table 1: Effect of micro-credit on poverty reduction

\begin{tabular}{|l|c|c|c|}
\hline \multicolumn{1}{|c|}{ Statements } & $\mathbf{n}$ & $\overline{\mathbf{x}}$ & $\boldsymbol{\sigma}$ \\
\hline $\begin{array}{l}\text { Micro-credit has led to improvement of } \\
\text { basic needs }\end{array}$ & 200 & 4.36 & 0.90 \\
\hline $\begin{array}{l}\text { The amount loaned increased for the last 5 } \\
\text { years }\end{array}$ & 200 & 4.19 & 0.74 \\
\hline $\begin{array}{l}\text { Preference of micro-credit from MFIs than } \\
\text { bank loans }\end{array}$ & 200 & 3.74 & 0.80 \\
\hline Mean Index $=4.10$ & & \\
\hline
\end{tabular}

Note: $n, \bar{x}$ and $\sigma$ indicate sample size, mean and standard deviation of the respondents. Source: Authors own estimation, field data (2018).

Table 1 shows the effect of micro-credit on poverty reduction in Bangladesh. Results indicate that majority of the respondents preferred micro-credit from MFIs than banks. The respondents also told that micro-credit improved their basic needs and their income earned per month increased due to expansion of business after getting loans from the MFIs. The results showed that the amount loaned by MFIs increased year after year and this had a mean value of 4.19 .

Table 2: Effect of micro-insurance on poverty reduction

\begin{tabular}{|l|c|c|c|}
\hline \multicolumn{1}{|c|}{ Statements } & $\mathrm{n}$ & $\overline{\mathbf{x}}$ & $\boldsymbol{\sigma}$ \\
\hline MFIs have various micro-insurance covers & 200 & 3.24 & 0.51 \\
\hline $\begin{array}{l}\text { Number of people with micro-insurance } \\
\text { covers }\end{array}$ & 200 & 3.12 & 0.45 \\
\hline Benefit of micro-insurance covers & 200 & 3.67 & 0.62 \\
\hline Mean Index $=3.34$ &
\end{tabular}

Note: $\mathrm{n}, \overline{\mathrm{x}}$ and $\sigma$ indicate sample size, mean and standard deviation of the respondents. Source: Authors own estimation, field data (2018).

Table 2 shows the effect of micro-insurance on poverty reduction. The results indicate that majority of the respondents having insurance covers (3.24 mean score), clients with insurance cover (3.12 mean score) and benefited from insurance covers (3.67) they received from the MFIs.

Table 3: Effect of savings on poverty reduction

\begin{tabular}{|l|c|c|c|}
\hline \multicolumn{1}{|c|}{ Statements } & $\mathbf{n}$ & $\overline{\mathbf{x}}$ & $\mathbf{\sigma}$ \\
\hline $\begin{array}{l}\text { The amount of savings made enabled me } \\
\text { to improve my lifestyle }\end{array}$ & 200 & 4.54 & 0.59 \\
\hline My savings have increased for the last 5 years & 200 & 4.07 & 0.77 \\
\hline $\begin{array}{l}\text { The higher the savings, the higher the } \\
\text { micro-credit }\end{array}$ & 200 & 4.29 & 0.80 \\
\hline Mean Index $=4.30$ & & \\
\hline
\end{tabular}

Note: $\mathrm{n}, \overline{\mathrm{x}}$ and $\sigma$ indicate sample size, mean and standard deviation of the respondents. Source: Authors own estimation, field data (2018).
Table 3 shows the effect of savings on poverty reduction and the results show that the amount of savings influences on the amount of micro-credit. Respondents also agreed that savings improved their lifestyles with a mean value of 4.54 and standard deviation of 0.59 . Income earned also increased because they were able to get higher amounts of micro-credit due to higher savings and this had a mean value of 4.29. Respondents said that their savings had increased for the last five years and this had a mean value of 4.07.

Table 4: Effect of training on poverty reduction

\begin{tabular}{|l|c|c|c|}
\hline \multicolumn{1}{|c|}{ Statements } & $\mathbf{n}$ & $\overline{\mathbf{x}}$ & $\boldsymbol{\sigma}$ \\
\hline MFIs organize trainings for its members & 200 & 4.48 & 0.72 \\
\hline $\begin{array}{l}\text { Trainings have enabled me save more } \\
\text { than before }\end{array}$ & 200 & 4.20 & 0.71 \\
\hline $\begin{array}{l}\text { Trainings have led to better usage of } \\
\text { Micro-credit }\end{array}$ & 200 & 4.22 & 0.77 \\
\hline $\begin{array}{l}\text { MFIs organize trainings after every three } \\
\text { months }\end{array}$ & 200 & 4.24 & 0.74 \\
\hline Mean Index $=4.24$ & & \\
\hline
\end{tabular}

Note: $n, \bar{x}$ and $\sigma$ indicate sample size, mean and standard deviation of the respondents. Source: Authors own estimation, field data (2018).

Table 4 shows the effect of training on poverty reduction and it indicates that majority of the respondents agree with the environment providing by MFIs which allows members to develop skills and talents, and acquire knowledge. The similar result was found in the study of Abraham (2015). He stated that the development of skills and talents among employees is one way through which employees feel engaged. The respondents agreed that the trainings help in better usage of micro-credit and have improved the saving trends. The respondents also argued that MFIs organize trainings for them.

Table 5: Income before and after acquiring MFIs services

\begin{tabular}{|l|c|c|c|}
\hline \multicolumn{1}{|c|}{ Statements } & $\mathbf{n}$ & $\overline{\mathbf{x}}$ & $\boldsymbol{\sigma}$ \\
\hline Income before & 200 & 3.50 & 0.50 \\
\hline Income after & 200 & 4.51 & 0.50 \\
\hline $\begin{array}{l}\text { Quality of life has improved due to MFI } \\
\text { services }\end{array}$ & 200 & 3.26 & 0.38 \\
\hline
\end{tabular}

Note: $\mathrm{n}, \overline{\mathrm{x}}$ and $\sigma$ indicate sample size, mean and standard deviation of the respondents. Source: Authors own estimation, field data (2018).

Table 5 shows the changes of income for having MFIs services. The results indicate that microfinance services increased the income earned by MFIs customers. Quality of life was also improved due to microfinance services.

The researchers conducted a multiple regression analysis so as to set the relationship among the dependent, poverty reduction and the independent variables namely; microcredit, micro-insurance, savings and training. The model summary table explains the goodness of fit of the model and the changes in the dependent variable explained by the change in the independent variables, the analysis of variance (ANOVA) table explains the significance of the 
regression model in relations to the differences in means of the dependent and independent variables and finally the regression coefficients table explains the changes of dependent variable in relation to the changes of independent variables by one unit if all things being equal.

Table 6: Model summary of the regression model

\begin{tabular}{|c|c|c|c|}
\hline $\mathbf{R}$ & $\begin{array}{c}\mathbf{R} \\
\text { Square }\end{array}$ & $\begin{array}{c}\text { Adjusted } \\
\text { R Square }\end{array}$ & $\begin{array}{c}\text { Std. Error of } \\
\text { the Estimate }\end{array}$ \\
\hline $0.607^{\mathrm{a}}$ & 0.368 & 0.355 & 0.397 \\
\hline
\end{tabular}

Source: Authors own estimation, field data (2018)

Table 6 shows the model summary of the regression model and it indicates that the model has a goodness of fit. The value of correlation is 0.607 indicates that there is a strong positive relationship between the dependent and the independent variables. The value of coefficient of determination is 0.368 indicates that savings, trainings, micro-insurance and micro-credit affects poverty reduction by $36.8 \%$ if other things remain constant.

Table 7: Estimated result of ANOVA

\begin{tabular}{|l|c|c|c|c|c|}
\hline & Sum of Squares & df & Mean Square & F & Sig. \\
\hline Regression & 17.944 & 4 & 4.486 & 28.424 & $0.000^{\mathrm{b}}$ \\
\hline Residual & 30.776 & 195 & 0.158 & & \\
\hline Total & 48.720 & 199 & & & \\
\hline
\end{tabular}

Source: Authors own estimation, field data (2018).

Table 7 shows the estimated result for ANOVA and it indicates that the regression model in relations to the differences in means of the dependent and independent variables is significant since the p-value $(0.000)$ of Fstatistic is less than $5 \%$ level of significance.

Table 8: Estimated coefficients of the regression model

\begin{tabular}{|l|c|c|c|}
\hline $\begin{array}{l}\text { Dependent Variable: } \\
\text { Poverty Reduction }\end{array}$ & Coefficients & Std. Error & p-value \\
\hline Constant & 0.205 & 0.415 & 0.621 \\
\hline Micro-credit & 0.336 & 0.056 & 0.000 \\
\hline Savings & 0.227 & 0.065 & 0.001 \\
\hline Micro-insurance & 0.222 & 0.077 & 0.004 \\
\hline Training & 0.184 & 0.046 & 0.000 \\
\hline
\end{tabular}

Source: Authors own estimation, field data (2018).

Table 8 presents the estimated parameters for the independent variables of the regression model. The result shows the expected sign of each of the variables and, the variables are significant. The result also shows that the maximum poverty reduction is possible with the help of micro-credit services and least by training services. The result may be different in other aspects. The results infer that a one-unit increase in micro-credit may have a 0.336unit increase on poverty reduction, ceteris paribus. Pitt et al. (2003) also found that micro-credit has significantly contributed for reducing poverty. Kumar et al. (2013) found that most of the micro-credit customers not only satisfied but also they thought that it has improved their life-style, increased their sources of income and increased to participate in the decision making process. A one-unit improvement in savings would yield a 0.227 -unit poverty reduction if all things being equal. Khandker and Chowdhury (1996) found the similar result in their study. They argued that microfinance has a positive impact on savings and asset accumulation too. They also argued that current savings of those who obtained micro-credit are many times higher than the savings of those who did not obtain credit. A one-unit increase in micro-insurance would yield 0.222 -unit increases in poverty reduction and a one-unit improvement in trainings would result to a 0.184 -unit increase poverty reduction if other things remain constant.

From the results above, the researchers argued that majority of the respondents preferred micro-credit from MFIs than the banks. The income of the respondents was increased due to expansion of business just after they acquired loans from the MFIs as well as improved their basic needs. The study suggests that the higher amount loaned from the MFIs incur higher savings of the respondent. The study also suggests that the respondents were more benefited from the insurance provided by the MFIs. The findings of the study also depict that MFIs provide a good environment ensuring necessary skills and talents required for proper business operation and management. The institutions also help them acquiring knowledge on the use of MFIs products and services. The training provided by the MFIs leads to better usages of loan and helps them save more than the before.

\section{CONCLUSION}

Poverty is a big problem in a developing country like Bangladesh as well as across the world. MFIs are recognized as an effective tool against poverty. The institutions are providing financial services to the people who do not have access to banks. The purpose of the study was to identify the impact of microfinance services on poverty reduction in Bangladesh and found that microfinance services play a very important role in poverty alleviation over the country.

The results show that micro-credit plays a great role in poverty reduction in Bangladesh. The services may help in poverty alleviation by ensuring amount received in terms of loan is used for the intended purpose. If this loan is used well then the living standards of individuals will improve thus for poverty reduction. Total income earned will increase if customers who get loan from MFIs start-up income generating units. The study also concludes that micro-credit help in poverty reduction by making finance access to low income earners, less educated and those in the informal sector. It also helps in expansion of business, acquisition of better residential places, access to education, health and improved welfare. The research concluded that the higher savings comes from higher the amount loaned. The amount can be used in improving the standards of individuals living. The savings may also increase year by 
year and can contribute to higher amounts of credit. The research also concluded that most MFIs had various microinsurance covers and thus the number of people with insurance covers was high. The large numbers of customers stated that they are benefited from these insurance covers. The research finally concluded that microfinance services on poverty reduction are of great benefit to the country as a whole and not only in Barisal division since it is only part of the country. Thus, most of the customers of microfinance institutions were in the informal employment and were the major beneficiaries of training as a service offered by MFIs to enable the customers to develop skills and talents as well as to have knowledge on how to save. The research also concluded that the trainings enabled customers to save more than they were saving before.

The study recommends that MFIs operating within Barishal division is to be empowered through provision of finances which can be advanced to the locals as loan to facilitate rapid economic growth. The study also recommends that MFIs should undertake regular training programs on financial management courses with a view to learn the best financial management skills and to improve their business. This may lead to higher income through alleviation of poverty. The government of Bangladesh may formulate and review the existing policies on MFIs to incorporate the emerging issues due to changes in the banking industry. However, it is important for microfinance programs to be well designed in order to best meet the needs of the poor customers they aim to serve. The government may also put strict measures to curb corruption and other evil vices that have infiltrated the microfinance programs. Financial education is recommended for the microfinance credit obtained by customers. This will ensure the loan is used for the intent purpose. Policy makers may also intervene and develop mechanisms to fight poverty which has remained intense.

The researcher recommends further research to be done on all MFIs in various areas over the country as this will ensure comprehensive and representative findings obtained on how microfinance help in poverty reduction. Future research can also be done using more variables included in the model. A study like this is also recommended on the effect of microfinance services on poverty reduction but done over a period of time whereby data will be collected after every three months for a period of ten years. The study may carry out examining MFIs exist to make profit, empower their clients or both.

\section{ACKNOWLEDGEMENT}

The researchers would like to thank the authority, Research and Training Centre (RTC), Patuakhali Science and Technology University for funding the project entitled "The Impact of Microfinance on Poverty Alleviation in Bangladesh: A Study on Barisal Division" and for its successful completion.

\section{REFERENCES}

Abraham, W. E. (2015). The Mind of Africa. Sub-Saharan Publishers.

Angelucci, M., Karlan, D., and Zinman, J. (2013). Win Some Lose Some? Evidence from a Randomized Microcredit Program Placement Experiment by CompartamosBanco. Institute for the Study of Labor (IZA), 7439, 71.

Anyanwu, C. M. (2004). Microfinance Institutions in Nigeria: Policy, Practice and Potentials. In G24 Workshop on "Constraints to Growth in Sub Saharan Africa," Pretoria, South Africa in November (pp. 1-31).

Armendáriz de Aghion, B., and Morduch, J. (2000). Microfinance beyond Group Lending. Economics of Transition, 8(2), 401-420.

Armendáriz, B., and Morduch, J. (2005). The Economics of Microfinance. MIT Press: Cambridge, MA.

Armendáriz, B., and Morduch, J. (2010). The Economics of Microfinance. Second Edition, United States of America: Library of Congress Cataloging-in-Publication Data.

Bakhtiari, S. (2006). Microfinance and Poverty Reduction: Some International Evidence. International Business \& Economics Research Journal (IBER), 5(12): 65-71.

Barr, M. S. (2004). Microfinance and financial development. Mich. J. Int'l L., 26, 271.

Ganle, J. K., Afriyie, K., and Segbefia, A. Y. (2015). Microcredit: Empowerment and Disempowerment of Rural Women in Ghana. World Development, 66, 335-345.

Gujarati, D. N. (2009). Basic Econometrics. Tata McGraw-Hill Education.

Kai, H. and Hamori, S. (2009). Microfinance and Inequality. MPRA Paper No. 17572, September 2009.

Khan, M. A., and Rahaman, M. A. (2007). Impact of Microfinance on Living Standards, Empowerment and Poverty Alleviation of Poor People: A Case Study on Microfinance in the Chittagong District of Bangladesh. Umea School of Business (USBE).

Khandker, S. R., and Chowdhury, O. H. (1996). Targeted Credit Programs and Rural Poverty in Bangladesh. The World Bank.

Kumar, D., Hossain, A., and Gope, M. C. (2013). Role of Micro Credit Program in Empowering Rural Women in Bangladesh: A Study on Grameen Bank Bangladesh Limited. Asian Business Review, 3(4), 114-120.

Ledgerwood, J. (1999). Sustainable Banking with the Poor Microfinance Handbook: An Institutional and Financial Perspective. The World Bank, Washington, D.C.

Littlefield, E., Morduch, J., and Hashemi, S. (2003). Is microfinance an effective strategy to reach the millennium development goals? Focus note, 24(2003), 1-11.

Morduch, J. (1999). The Microfinance Promise. Journal of economic literature, 37(4), 1569-1614.

Microcredit Regulatory Authority. (2017). NGO-MFIs in Bangladesh. Microcredit Regulatory Authority (MRA), Dhaka, Bangladesh.

Otieno, S., Martin, L., Nyamao, N. R., Ojera, P., and Odondo, A. J. (2013). Effect of provision of micro-finance on the performance of micro-enterprises: A study of youth microenterprises under Kenya Rural Enterprise Program (K-REP), Kisii County, Kenya. 
Pitt, M., Khandker, S., and Cartwright, J. (2003). Does Micro-credit Empower Women? Evidence from Bangladesh. The World Bank.

Ravallion, M. (2001). Growth, inequality and poverty: looking beyond averages. World development, 29(11), 1803-1815.

Roodman, D., and Morduch, J. (2014). The impact of microcredit on the poor in Bangladesh: Revisiting the evidence. Journal of Development Studies, 50(4), 583-604.

Schuler, S. R., Hashemi, S. M., \& Riley, A. P. (1996). Rural Credit Programs and Women's Empowerment in Bangladesh. World development, 24(4), 635-653.
Schwab, K. (2017). The Global Competitiveness Report 20172018. In World Economic Forum, 58-59.

Van Rooyen, C., Stewart, R., and De Wet, T. (2012). The impact of microfinance in sub-Saharan Africa: a systematic review of the evidence. World Development, 40(11), 2249-2262.

Wanchoo, R. (2007). Micro-finance in the India: The Changing Face of Micro-credit Schemes. DOI: https://mpra.ub.unimuenchen.de/3675/1/MPRA_paper_3675.pdf.

$--0--$

Appendix 1: Details of Micro Finance Institutions (MFIs) in Bangladesh

\begin{tabular}{lrrr}
\hline \multicolumn{1}{c}{ Particulars } & June, 2015 & June, 2016 & June, 2017 \\
\hline No. of Licensed MFIs & 753 & 758 & 783 \\
No of Branches & 15,609 & 16,284 & 17,120 \\
No. of Employees & 110,781 & 127,820 & 139,526 \\
No. of Clients (Million) & 26.00 & 27.79 & 29.91 \\
Total borrowers (Million) & 20.35 & 23.28 & 24.85 \\
Loan Disbursement (TK. Billion) & 634.00 & 787.00 & $1,046.12$ \\
Agri. Loan Disbursement (Tk. Billion) & 266.25 & 353.00 & 408.88 \\
Amount of Loan Outstanding (Tk. Billion) & 352.41 & 459.37 & 583.62 \\
Agri. Loan Outstanding (Tk. Billion) & 147.60 & 285.00 & 354.00 \\
Amount of Savings (Tk. Billion) & 135.41 & 171.19 & 216.71 \\
\hline
\end{tabular}

Note: 56, 78 and 84 MFIs were cancelled at the end of June 2015, 2016 and 2017 respectively; Source: MRA-MIS Database, 2017

\section{How to Cite This Article}

Badiuzzaman, Uddin, M. H., \& Hossain, A. (2020). Impact of Microfinance on Poverty Alleviation: A Study in the Southern Part of Bangladesh. Asian Business Review, 10(2), 81-86. https://doi.org/10.18034/abr.v10i2.465 